\title{
Strategy of Non-Formal Education Development Through En- trepreneurial Skills at CLC Budi Utama Surabaya
}

\author{
Widodo Widodo ${ }^{*}$, Ira Darmawanti², Novia Nur Kharisma ${ }^{3}$ \\ ${ }^{1}$ Universitas Negeri Surabaya, Indonesia \\ ${ }^{2}$ University of Vienna, Austria \\ ${ }^{2}$ PKBM Budi Utama, Indonesia \\ *Email: widodo@unesa.ac.id
}

Submitted: 21 October 2020. Revised: 13 November 2020. Accepted: 23 February 2021

\begin{abstract}
The development of urban community needs for increasing self-competence is a great opportunity for Non-Formal Education (NFE), but the NFE program organized by Community Learning Centre (CLC) has not been able to answer. It needs the right strategy to develop NFE programs that are in accordance with the needs of urban communities, namely entrepreneurship. The research objective was to reveal the urban area entrepreneurship based NFE program development strategy carried out by CLC. The research used a descriptive qualitative approach, with the following research results. Entrepreneurship-based NFE program development strategy through stages; (1) strategy formulation which includes activities to identify potentials, formulate the vision, mission and objectives of the CLC institution, identify internal and external conditions of the CLC institution, select strategies, formulate strategies. (2) Implementation of culinary entrepreneurship strategies with attention to urban problems, effective organizational structures, marketing programs, budgets, developing management information systems, and linking with performance. (3) Evaluation of culinary entrepreneurship strategies; the effectiveness of the process and the achievement of results, namely the learning community has skills as a provision for entrepreneurship. This NFE program management strategy can solve the problem of unemployment, and for CLC institutions to develop and become independent. The conclusion is that the strategy of developing the NFE program based on entrepreneurial skills can create graduates who are ready to become entrepreneurs. So that graduates can provide benefits for their own life and social environment.
\end{abstract}

Key words: skills, entrepreneurship, non-formal education, strategy

How to Cite: Widodo, W., Darmawanti, I., \& Kharisma, N. N. (2021). Strategy of Non-Formal Education Development Through Entrepreneurial Skills at CLC Budi Utama Surabaya. Journal of Nonformal Education, 7(1), 23-31.

DOI: http://dx.doi.org/10.15294/jne.v7i1.26796

\section{INTRODUCTION}

Non-formal education (NFE) has an important role and function in encouraging a learning society. NFE can be a substitute for formal education through the equality of pursuing education Packages A, B, and C. To get this "equality", it is necessary to manage a quality equality education program that refers to a predetermined standard and is able to have an impact on community empowerment as a result of learning. Moreover, graduates who can meet industrial needs are really needed, so NFE is very much needed (Mulyadi et al., 2020)

The implementation of the NFE program includes the first is from the community which means that the NFE program comes from community initiatives. Second, the PNFE program is organized by the community, which means that planning, organizing, implementing, monitoring and evaluating is fully the responsibility of the community or community organization. The three PNF programs are for the community which means that the PNF program is fully aimed at meeting the learning needs of the community for the advancement and empowerment of community life. The existence of the PNF institution is very important as the basis for implementing PNF programs in accordance with community needs or community empowerment. (Rizka \& Hardiansyah, 2016)

CLC is an educational unit that organizes the NFE program in accordance with the needs of the community to increase the knowledge, skills, attitudes, hobbies and talents of community members which start from the meaning and benefit of the program for learning citizens by exploring and utilizing the potential of human and natural resources in their environment (Sihombing, 1999);(Widodo, 2015). The NFE program organized by CLC Budi Utama Surabaya due to community needs, dropouts and unemployment. NFE program services that can empower urban communities who experience work problems. The facts show that there are still many children dropping out of school because of funding, the sense of comfort in school. Data on children who did not go to school from the Surabaya City Education Office reached 1,440 children and 11,440 vulnerable to dropout. Based on the 2016 census, the population in Jambangan District has an area of $385167 \mathrm{~m} 2$ with 4 urban villages with a population of 23,193 people. Based on these conditions, education is a shared responsibility between the family, government and society, so that direct community involvement in the education process will make a major contribution to national development, especially regional autonomy 
development. To meet the needs of the community in accordance with the problems and needs of the community, PKBM Budi Utama has been built since 2007.

CLC is a unit that organizes learning in the form of various kinds of skills by utilizing the facilities, infrastructure and all the potential that exists around the community's environment. CLC is one of the alternatives chosen and used as a community empowerment process, emphasizes that participation is community involvement in the NFE programs (Chambers, 1996). Community participation in every NFE program management process is a form of response to the NFE program which is carried out in the form of community involvement (learning citizens) in making decisions (Arbarini et al., 2018). UNESCO reported a problem in the management of the CLC, namely maintaining the sustainability of the NFE program(UNESCO, 2008). To maintain the sustainability of the NFE program, a sound management strategy is needed. The NFE program is encouraged to be independent by adding entrepreneurial skills, conducting more authentic evaluations, emphasizing community participation, generating community participation by all means, collaborating in monitoring and supervision, and needing support from the government and other institutions(O'Connor, 2012).

The objectives of providing entrepreneurial skills in the Package C program are (1) to instill an entrepreneurial spirit, attitude and ethics to students, (2) to provide knowledge about entrepreneurship, (3) to provide skills in the production of goods or services, ( 4) train entrepreneurial skills through practice, (5) encourage and create new entrepreneurs through entrepreneurship learning(D. Hidayat, 2017). Suggests entrepreneurial skills provided to learning citizens are related to; managerial skills, conceptual skills, human skills, decision making skills, and time managerial skills. So that the provision of entrepreneurial skills to learning citizens is a strategy in developing the NFE program(Mulyadi et al., 2020).

The strategy to develop the NFE program determines the success of the implementation of programs and services for the community. This study focuses on the management strategy for the development of the NFE program organized by CLC. The program development strategy includes processes that refer to strategic management functions. The strategic management aspect includes the vision of the institution, the factual conditions of the institution, the ideal conditions desired, the problems of the institution, and the stages in developing the CLC institution.

Management is an effort to mobilize all the potential that is owned in achieving the goals and targets that have been set. That management always involves efforts to coordinate and supervise other people's work activities so that their activities are completed efficiently and effectively(Coulter, 2012). Management is the process of planning, organizing, directing and supervising the efforts of organizational members and the use of other organizational resources in order to achieve predetermined organizational goals(Sudjana, 2004). Management emphasizes the "process" carried out by managers including planning, organizing, directing and monitoring. Management is about a specific process consisting of planning, organizing, implementing and monitoring the use of each science and art together and then completing tasks to achieve goals(Terry, 2012). However, there are differences in management due to point of view, point of view, object of study and because the term is studied from various perspectives(Yukl, 2005);(Sudjana, 2004).

Strategic management starts with a fundamental question, namely how to achieve goals quickly? For that requires an NFE program including; condition and position of the institution and the current NFE program, in which direction the NFE program will be developed which is summarized in the vision and mission, and how to achieve the desired NFE program conditions based on the conditions of the institution or program. Strategic management is a series of managerial decisions and actions that determine the company's long-term performance(Hunger \& Wheelen, 2003). Strategic management includes environmental observation, strategy formulation (strategic planning or long-term planning), strategy implementation and evaluation and control. Stated that there is a need for a strategy to manage the NFE program so that it is consistent and has a big influence on learning citizens and children's success(Shofwan et al., 2019) .

The development of the NFE program organized by CLC answers the needs of urban communities, namely unemployment. The NFE program that is held is able to alleviate unemployment by providing entrepreneurial skills. The NFE program is also in accordance with community needs, namely according to the type of program, targets, community characteristics, resources and so on. NFE program development strategy management means activities that are systematically carried out to achieve goals quickly and in the best possible way. The management of the NFE program is the process of moving other people to cooperate in a planned, organized, well-controlled and measured manner, and based on flexibility and participation, both individually and in groups to achieve goals effectively and efficiently. Package C learning cover planning, learning and evaluation. The learning plan for the Package C Program includes: formulating learning objectives, preparing teaching materials, preparing teaching methods, choosing 
learning resources, and establishing assessment of learning outcomes(Sufyan et al., 2019);(Dunn, 2012).

Quality management in institutions, namely; (1) intense focus on the customer, (2) concern for continual improvement, (3) process focused, (4) improvement in the quality of everything the organization does, (5) accurate measurement, (6) empowerment of employess(Coulter, 2012);(Sallis, 2005). Aspects that must be considered in program development strategy management are current conditions, desired ideal conditions, formulation of gaps and problems, alternative activities, the best way to achieve ideal conditions(Yusanto \& Karebet, 2003). NFE program development strategy management is carried out on the grounds that it focuses on management, covers processes, fosters common awareness, connects key factors, and can reach the peak of development. The management focus places an emphasis on predicting dynamic environmental changes in planning the development of the NFE program. The scope of the large-scale and wide-scale management process that is contained in the vision, mission and objectives of the CLC through the NFE program. Raising awareness together to achieve the goals of the NFE program that can provide solutions to community problems. Linking the role of success factors in developing the NFE program, namely; environment, resources and stakeholder objectives. Record the development process of the NFE program to determine the reliability of the strategies used(Salman \& Tohari, 2019).

The management strategy for developing the NFE program includes the following aspects; 1) current program conditions, 2) ideal conditions for planned programs, 3) gaps between ideal conditions and current conditions, 4) the right way to accelerate the achievement of the ideal program, 5) the influencing environment.

\section{METHOD}

The research approach used is qualitative research to investigate social phenomena to get the meaning of the natural process of strategic management at CLC Budi Utama. Qualitative research is a process of inquiry based on an understanding of a different methodological tradition from investigations that explore social problems, fully describing the phenomena that occur(Creswell, 2007);(Bogdan \& Biklen, 1992).

This study uses a case study type in qualitative research methods to explain a natural process of the NFE program strategy(Creswell, 2007). Data analysis is a systematic process of searching for and organizing transcripts of in-depth interviews, field notes, documentation and other materials that are collected to increase the understanding of researchers and which are studied to present what has been found(Bogdan \& Biklen, 1992). Steps taken to analyze qualitative research data by collecting data, data reduction, data presentation, drawing conclusion(Huberman, 1973). Data collection and reduction techniques; dept-interview, participant observation, documentation. Then classify the data according to what is needed. Classifying according to the NFE program development strategy in the CLC. Data classification according to data source, data type, technique used, time and place. Data verification and interpretation results are carried out by involving managers or experts to check the results obtained from carefully carried out data analysis. So that the results will be written as the best conclusion.

\section{RESULTS AND DISCUSSION}

Strategic The development of the NFE program is carried out by compiling a plan made by CLC Budi Utama involving several parties including the chairman of the CLC, tutors and management staff. The planning is carried out every time before the beginning of the new academic year, namely determining the lesson schedule, determining the tutor if it is deemed not optimal in providing learning, determining the agenda or schedule of activities or programs for the year. Planning includes outing classes / study tours, comparative studies, parenting and coaching, consulting activities through the zoom application, budget allocation, determining the schedule of learning evaluation activities according to the educational calendar, the process of admitting students related to completeness of files or requirements.

"kita membuat rencana dan target yang akan capai, ini sangat penting dilakukan untuk kemajuan PKBM. sebelum perencanaan dilakukan, kita melakukan refleksi terhadap program yang telah dilakukan, menata ulang potensi, dan target yang ditetapkan, setelah itu rencana secara detail dibuat" (We make plans and targets that will be achieved, this is very important for the progress of CLC. before planning is carried out, we reflect on the program that has been carried out, rearrange the potential and targets set, after which a detailed plan is made "(Head of CLC)

"saya sebagai tutor juga membuat rencana pembelajaran, menyiapkan perangkat pembelajaran paket $C$. Menyusun rencana diikuti semua orang PKBM dan diberi kesempatan untuk usul untuk dikerjakan bersama"(As a tutor, I also made lesson plans, prepared learning tools for package C. Preparing plans followed by all CLC people and given the opportunity to submit proposals to be worked on together" (Mega tutor) 
Program organization was very flexible and provided everyone involved to actively coordinate with the team. So that it creates family communication at CLC and provides comfort in carrying out tasks. The implementation of equivalency education Packages B and $\mathrm{C}$ is carried out by all organizers, tutors and all students as in the CLC Budi Utama organizational structure. Equality Package B education is carried out three days a week, namely Monday, Tuesday and Wednesday starting at 19.00-21.00 WIB with a duration of one subject is 45 minutes. Learning Package $C$ shows that one subject is carried out for 45 minutes. Learning Package $\mathrm{C}$ is carried out 5 days a week, namely on Monday, Tuesday, Wednesday, Thursday and Friday. starts at 19.00-21.00. In its implementation, sometimes there are still students who come late in following the learning process for reasons of working. Evaluation of the Package B and C equivalency Education program in its implementation is usually carried out with all educators / tutors, education staff and the head of the organizer. This evaluation process is carried out at the end of each semester, but if there are deficiencies and it has not been as expected.

Lack of implementation of the NFE program includes still less competent teaching staff or learning resources, which affects their way of learning, students' low learning motivation, and focus on administration. Entrepreneurial skills for empowerment are a strategy for developing the NFE program (Bush \& M, 2005);(Hoppers, 2006). The management of the NFE program is a systematic, comprehensive cooperation process in the context of realizing educational goals, as well as giving authority to the head of the institution, educators, education personnel in planning, organizing, teaching, monitoring and evaluating students. Likewise, the strategy for managing institutional units through the culinary business skills (life skills) at CLC Budi Utama.

The strategy for developing the NFE program is carried out by looking at and analyzing the potential around, applying this potential in the Kedai Pinggir Kali (KPK) independent business program and the Friday Blessing program. The two activity programs in the culinary field, apart from being carried out with independent business objectives, are also carried out with the aim of training the skills (life skills) of students of the package $C$ equivalency program. (1) providing students with skills to be developed after they pass the package $\mathrm{C}$ equivalency, (2) developing new businesses and innovating in the culinary field so that they can improve their standard of living, (3) CLC Budi Utama's culinary business is able to manage the institution independently both from in terms of operational financing and independence in terms of institutional program development.
The prototype for learning entrepreneurial skills through culinary is as follows.

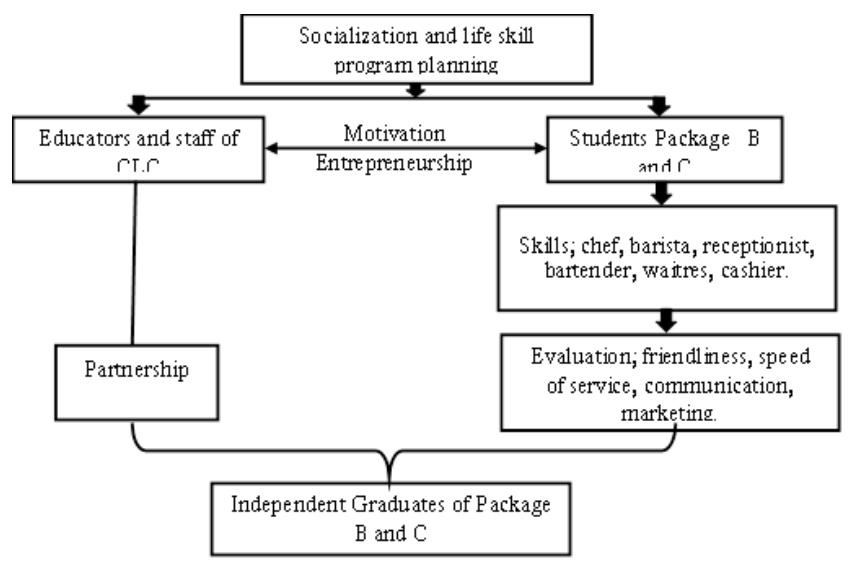

Figure 1. Prototype of collaborative learning entrepreneurial skills

The skills activity program through the culinary business is a management strategy for the CLC Budi Utama unit which was developed with the aim of providing good skills to students, educators, education staff, and the community. The implementation of management strategies through entrepreneurial skills at CLC Budi Utama, namely (1) through apprenticeship of package $\mathrm{C}$ equivalency students at Kedai Pinggir Kali (KPK) by equipping Chef, barista, receptionist, bartender, waiter / waitress, and cashier skills. (2) Through apprenticeship with the aim of equipping students' skills in terms of consumer friendliness, speed of service, communication to consumers, and food marketing.

The management procedures carried out by CLC Budi Utama in life skills activities through the culinary business are as follows. (1) The head of the CLC Budi Utama institution unit leads the socialization and design of the life skill program to CLC Budi Utama educators and educational staff. (2) Educators and education personnel conduct socialization, coaching and entrepreneurial motivation to students of the equality program and the community who want to get life skills at CLC Budi Utama. (3) After receiving coaching, students form groups of at least 5 people to practice life skills in the culinary field (food). (4) After they have formed a group the next step is to determine the life skill schedule. The practice schedule is flexible according to the free time of students. (5) Culinary field practice activities.

The graduation standard criteria that must be achieved by students in the life skills program are: a) Taking 5 practical meetings with a duration of 3 hours of each meeting, students may choose to focus on culinary practice at Kedai Pinggir Kali (KPK), focus on practice, as well as a combination of the above activities, b) students are required to attend every practical activity they participate in, c) students 
are able to carry out procedures in culinary field services at CLC Budi Utama. Wearing a special uniform that has been provided by CLC Budi Utama; serve customers in a friendly, polite and polite manner; dexterity in service; maintain cleanliness and maintain the quality of the taste of cuisine. d) Students are able to apply culinary business practices (life skills) with the fields they are interested in in accordance with the instructor's instructions, e) students in the equality program if after graduation they are able to open culinary (food) businesses independently to confirm to CLC manager Budi Utama in order to be partners and provide motivation.

\section{Strategic in NFE development}

Non-formal education is organized outside the school system. Non-formal education is any organized, systematic, educational activity carried on outside the framework of the formal system to provide selected types of learning to particular subgroups in the population, adults as well as children. In its development, good management is needed, especially with regard to independence(Combs \& Ahmed, 1985);(Yoo, 2012). However, it is still based on the characteristics of NFE, which is flexible(Rogers, 2005).

That strategic management is an art and knowledge in formulating, implementing and evaluating cross-functional decisions in an organization that enable them to achieve goals(David, 2011). Stated several forms of NFE program innovation developed at CLC through boat accessories skills training programs, marine fish processing entrepreneurship training programs, life skills training, Muslim fashion mode courses, bridal makeup programs(Rizka \& Hardiansyah, 2016).

According to Widodo research there is a model for managing CLC, namely the Organizing Entrepreneur Model(Widodo, 2019). This model maintains the continuity of the NFE program by creating business on the CLC. CLC is a learning institution and at the same time a place for economic businesses that can accommodate learning citizens in the form of the types of businesses they run. In the management of this model, CLC can run independently with financial support from established entrepreneurs. Even graduates who have entrepreneurial skills can become partners as resource persons, trainers, internships, and donors of the NFE program.

The Organizing Entrepreneur Model has a strategy to develop the independence of the CLC institution by adding life skills for every learning citizen. Even CLC can play a role in creating new entrepreneurs who can contribute as partners and instructors for skilled workers.

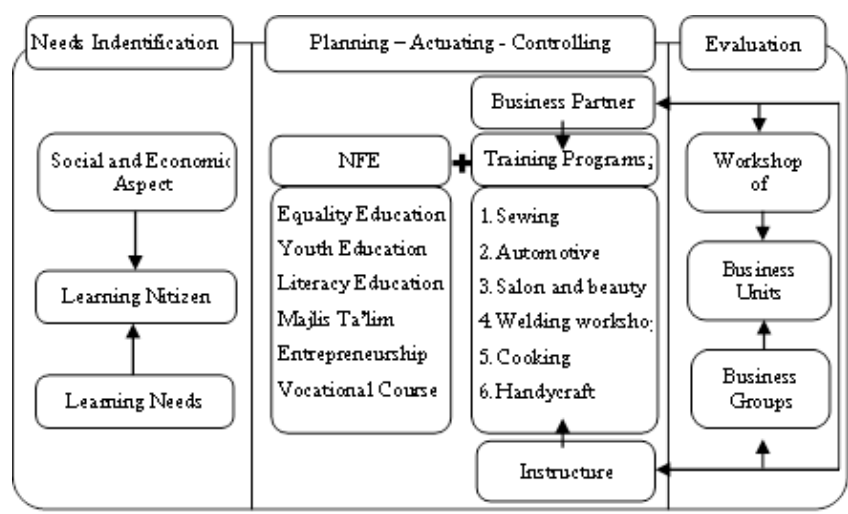

Figure 2. Organizing Entrepreneur Model in CLC

The NFE development strategy at CLC Budi Utama has a different character because it is located in an urban area. The development of the NFE program carried out by CLC can be described in the following development flow.

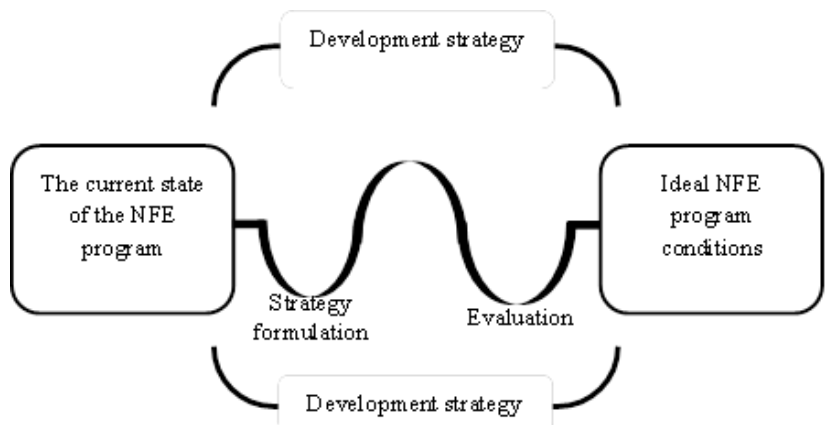

Figure 3. The flow chart of the NFE program development strategy

The figure shows the strategic process of developing the NFE program carried out by CLC. The program development strategy process stage includes; strategy formulation, strategy implementation, and evaluation of the NFE program.

\section{Strategy Formulation}

The initial stage in strategy formulation involves developing a vision, identifying external opportunities and threats in developing the NFE program, analyzing internal strengths and weaknesses of the CLC, formulating long-term goals, producing alternative strategies, and selecting specific strategies to achieve goals.

1) Identification of the potential of CLC that can be used as capital, namely the potential for the environment, human resources, social environment, all of which are the basis for institutional development. This potential becomes social capital and material capital to develop the NFE program.

2) Formulating the vision, mission and objectives of the CLC institution. Vision derives its translation into the mission, and the mission is developed into goals that can be achieved. CLC's vision is "to be- 
come an educational institution capable of developing a generation that is smart, creative, and ready to face the challenges of the times". The mission carried out by CLC Budi Utama, namely (1) developing all abilities possessed by students according to the stage of development, (2) laying the basics towards the development of attitudes, knowledge, and skills of students.

3) Identification of internal and external conditions of the CLC institution. Analyzing internal and external conditions, such as identifying data trends that lead to the conditions of the socio-cultural, socioeconomic, technological and political environments. This data trend can affect in the future by analyzing the market for the NFE program, competitors, and government policies that can be circumvented in developing NFE.

4) Choosing a Strategy. Strategies in the form of programs that can be applied and measured to achieve the vision, mission and goals.

\section{Strategy Implementation}

At this stage, the development of a culturesupporting strategy, an effective CLC organizational structure, restructuring marketing program efforts, preparing budgets, developing management information systems, and linking to performance is carried out. Performance still needs to be improved along with the many demands of work. It is hoped that graduates can work well in the culinary field in Surabaya or in other cities.

The strategy for developing the NFE program with entrepreneurial skills in the context of empowerment provides great support, through educational programs, economic efforts and awareness raising community participation in development. Learning entrepreneurship skills as an NFE development strategy by integrating equality education programs with entrepreneurial skills(Marcus \& Harper, 2019);(Kindervatter, 1979). The skills provision program is carried out to support the empowerment of citizens to learn the equivalence education A, B, C. Equality education packages $\mathrm{B}$ and $\mathrm{C}$ are mandatory programs in providing educational services for community members who do not have the opportunity to receive junior high school or high school education(Yatimah, 2016). The existence of equality education is very important considering that there are still many junior high and high school aged children who experience drop out for various reasons. Conducted a research experiment on practical non-formal education activities for students in schools, the result was that students had a strong enthusiasm for carrying out activities(Gloria et al., 2014).

Indeed, in reality there are conditions that are still not ideal as the objectives of implementing the equiv- alence program packages B and C. Various problems are faced by the delivery of equality education; 1) attendance level of learning citizens, 2) professionalism and number of teaching staff (tutors), 3) educational support facilities. Equality education packages $\mathrm{B}$ and C conducted by CLC Budi Utama were given additional material on culinary entrepreneurship skills that could be used as a job or a livelihood. This is done by CLC so that citizens learn equality education to actively participate and become a job solution for graduates(Nurhamidah et al., 2020).

The NFE program was developed in conjunction with the fields of economics and entrepreneurship aimed at improving the economic standard of the community. Various types of economic business that are carried out include; culinary and outbound fields are forms of entrepreneurship that have been carried out by the CLC institution. These entrepreneurial skills are tailored to the identification of the local potential of the city of Surabaya. The city of Surabaya is a metropolis area where people gather and meet to try their luck and look for jobs. This is a great potential to open a culinary business. Food is a basic human need that must be fulfilled every day. This potential is what drives CLC Budi Utama to provide skills in the culinary field for participants pursuing packages B and C. Entrepreneurial skills are developed using various approaches with the aim of becoming a superior or supporting program that can ensure the sustainability of the package $\mathrm{B}$ or $\mathrm{C}$ equivalency education program. Effective learning requires support from the chairperson of the CLC, facilities and infrastructure, capacity building so that it can achieve learning objectives (Smet et al., 2016) .

The strategies used to attract the public's interest to join and participate in the activities organized by the CLC are several things, including: First, socialization to the public about the NFE program that will be or is being held either in person, community radio or by placing banners. Second, by holding competitions for every activity either by participating in competitions organized by the education office and government agencies as well as independent competitions organized by CLC. Third, through religious activities by inserting information during religious activities, both at places of worship and at CLC locations. Fourth, with a holistic approach, meaning by asking community leaders for help to socialize CLC programs.

Based on the analysis, the findings from research on NFE development strategies through entrepreneurial skills that can be used as institutional reinforcement for CLC are as follows.

1) Provide added value with vocational skills. The equality education program that is held referring to the current and future needs of society is a form of 
initiation that can provide inspiration for the community. Equality education programs integrated with culinary and outbound entrepreneurship are able to have a good impact. The NFE program is the result of creativity that is able to arouse the community to participate in the equality education program organized by PKBM and gain additional skills that become entrepreneurial capital(Chang \& Yoo, 2012).

2) Facilitating the implementation of community activities in the NFE program with the facilities and infrastructure owned by CLC Budi Utama. Empowerment of citizens to learn equality education by providing culinary entrepreneurship skills that will become provisions after graduation. The role of tutors and CLC as facilitators in implementing active learning (Jeffs \& Smith, 2005).

3) Advocacy and business guidance for learning citizens. Advocacy and business guidance are provided to all learning citizens who want to open a culinary business. This is done as an integral part of the NFE program development strategy. The condition of the learning citizens with various backgrounds has different motivations in joining the NFE program. Meetings in the equality education program that are held are a place to motivate fellow citizens to learn. Multidirectional motivation, namely from tutors to learning citizens, from learning citizens to other learning citizens, from learning citizens to tutors. So that strengthen each other. Likewise in the implementation of entrepreneurship, by providing interest-free loans, cooperating in animal husbandry and fisheries businesses are motivation for learning citizens.

\section{Strategy Evaluation}

Evaluation of strategy implementation is seen from the output produced, namely graduates. Graduates of the package $\mathrm{C}$ program work both as business owners and are still following others, the better the strategy is implemented. The evaluation of the NFE program development strategy can be seen from the process and the results. The development implementation process goes through 3 stages, and the results can be seen in the empowerment of learning citizens. Empowerment or strengthening literally means 'to be strong' but in the social field it means more than that. Empowerment is concerned with how people gain collective control over their lives, thereby achieving their goals as a group. In a social context, empowerment is a method used to increase the strength of people who are lacking(Hardina et al., 2006).

Empowering is defined in various contexts (Clutterbuck, 2003), as follows. 1) Empowerment is an effort to find new ways to concentrate power in the hands of those who need it most to carry out work. This is done by assigning authority, responsibility, resources and rights at the level most appropriate to each task. 2) Delegate responsibility for decision making to the extent possible under the line of management. 3) Controlled transfer of power from management to employees to achieve the company's overall long-term goals. 4) Efforts to create situations and conditions in which people can use their maximum qualities and abilities to achieve common goals, both humanitarian goals and profit gain. 5) The psychological energy that activates everyone in the organization to work voluntarily.

That empowerment must pay attention to principles. The principle of empowerment must encourage people to determine for themselves what to do in dealing with the problems they face, with the awareness and power they have(Rukminto Adi, 2003). Empowerment is a condition in which a person or group is able to change their personal circumstances or environmental factors that contribute to difficulties in obtaining adequate goods, services, status, or life opportunities. The condition of an institution is empowered if it has moved from an institution that has never initiated a program to an institution that; 1) able to solve their own problems, 2) able to provide suggestions for solutions to others, 3) have the skills to work without being supervised(Hardina et al., 2006).

The development of the NFE program prepared by the CLC involves participatory learning citizens and stakeholders. This is a strategy so that the NFE program can be followed by learning citizens well. The NFE program was developed by adding entrepreneurial skills for learning citizens. In connection with the entrepreneurial skills program that is held, it has a function as a supporter of other programs such as equality, literacy, and being a leading program. The entrepreneurial skills program is a "key program" to maintain the sustainability of other NFE programs. Entrepreneurial skills programs can generate skilled human resources as well as sources of funds. CLC Budi Utama, which develops culinary, outbound, and other entrepreneurship entrepreneurship, becomes the supporting capacity for the equivalence program packages $\mathrm{B}$ and $\mathrm{C}$. The community learns to get additional gemstone life skills after the equivalence learning process.

\section{CONCLUSION}

The strategy for developing the NFE program through providing entrepreneurial skills at CLC can be carried out through the following stages; the first stage, the formulation of a strategy which includes activities (1) identification of potential, formulating the vision, mission, and goals of the PKBM institution, (2) identifying internal and external conditions that support the NFE program, (3) selecting strategies and formulating strategies. The second stage is the 
implementation of a predetermined strategy by taking into account (1) community potential, (2) sociocultural conditions, (3) effective management of the NFE program, (4) rearranging the marketing program efforts, (5) preparing a budget, (6) developing management information systems, and (7) relating to performance. The third stage, evaluation of strategies to determine the process of developing the NFE program and the achievement of the resulting output, namely the empowerment of learning citizens.

The conclusion is that the strategy of developing the NFE program based on entrepreneurial skills can create graduates who are ready to become entrepreneurs. This NFE program management strategy can solve the problem of unemployment, and for CLC institutions to develop and become independent, and that graduates can provide benefits for their own life and social environment.

\section{REFERENCES}

Arbarini, M., Jutmini, S., Joyoatmojo, S., \& Sutarno. (2018). Effect of Participatory Learning Model on Functional Literacy Education. Journal of Nonformal Education, 4(1), 13-24.

Bogdan, \& Biklen. (1992). Qualitative research for education: an introduction to theory and methodssecond edition. Allyn and Bacon.

Bush, T., \& M, D. (2005). Leading and Managing People in Education. SAGE Publication.

Chambers, R. (1996). Participatory Rural Appraisal (PRA); Memahami Desa Secara Partisipatif. Kanisius.

Chang, \& Yoo. (2012). Popular education for people's empowerment in the Community Learning Center (CLC) project in Bangladesh. Journal Korean Educational Development Institute (KEDI), Vol.9(no.2), 363-381.

Clutterbuck. (2003). The Power Of Empomerment; release the hidden Talent of your employees ( alih bahasa; B. Hidayat (ed.)). PT. Gramedia.

Combs, \& Ahmed. (1985). Attacking Rural Poverty, How Non-Formal Education Can Help (T. YIIS (ed.)). CV. Rajawali.

Coulter, S. R. \& M. (2012). Management, 11th Edition. Prentice Hall.

Creswell. (2007). Qualitativae inquiry and research design choosing among five traditions (Second Edi). SAGE Publication.

David, F. R. (2011). Strategic Management: Manajemen Strategi Konsep (12th ed.). Salemba empat.

Dunn, M. (2012). Nonformal, Informal Education And Poverty Reduction - A Role For Tvet? International Journal Of Education, Vol. 6(NO. 2), 97106.
Gloria, R., Tatiana, D., Constantin, R. B., \& Marinela, R. (2014). The effectiveness of non-formal education in improving the effort capacity in middleschool pupils. Procedia - Social and Behavioral Sciences, 116, 2722-2726.

Hardina, D., Middleton, J., Montana, S., \& Simpson, R. A. (2006). An Empowering Approach to Managing Social Service Organizations. Springer Publishing Company.

Hidayat, D. (2017). Pengelolaan Pembelajaran Berbasis Kewirausahaan Masyarakat Program Kejar Paket C. Journal of Nonformal Education, 3(1), $1-10$.

Hoppers, W. (2006). Non-Forml Education and Basic Education Reform; a Conceptual review. IIEP Production.

Huberman. (1973). Understanding Change in education: an Introduction. IBE.

Hunger, \& Wheelen. (2003). Manajemen Strategis. Andi Publishing.

Jeffs, T., \& Smith, M. (2005). Informal EducationConversation, Democracy and Learning. educational Heritics press.

Kindervatter, S. (1979). Nonformal Education as an Empowering Process with Case Studies from Indonesia and Thailand. Center For International Education.

Marcus, R., \& Harper, C. (2019). Does no-formal education have lasting effects? Compare: A Journal of Comparative and International Education, 15(1).

Mulyadi, D., Suryadi, \& Aliyyah, R. R. (2020). Skills Education Program: Is it Beneficial for the Society? Journal of Nonformal Education, 6(2), 101106.

Nurhamidah, Elvia, R., Handayani, D., \& Amida, N. (2020). Pemberdayaan kelompok tani melalui pembuatan bioenergi pertanian dari limbah batang pisang. Jurnal Pendidikan Dan Pemberdayaan Masyarakat, 7(2), 201-210.

O'Connor, U. (2012). Schools together: enhancing the citizenship curriculum through a non-formal education programme. Journal of Peace Education, 9(1), 31-48.

Rizka, A., \& Hardiansyah. (2016). Strategi Pengembangan Inovasi Program Pendidikan Non Formal Sebagai Best Practices Bagi Pusat Kegiatan Belajar Masyarakat. Jurnal Pendidikan Dan Pemberdayaan Masyarakat, 3(2), 187-196.

Rogers, A. (2005). Non Formal Education: flexible schooling or participatory education? Universities of Nottingham \& East Anglia.

Rukminto Adi, I. (2003). Pemberdayaan Pengembangan Masyarakat dan Intervensi Komunitas. LPFE UI. 
Sallis, E. (2005). Total Quality Management, thirt edition. Taylor \& Francis e-Library.

Salman, M. A., \& Tohari, E. (2019). Pemberdayaan masyarakat kawasan industri pertambangan melalui penyelenggaraan program paket C. Jurnal Pendidikan Dan Pemberdayaan Masyarakat, 6(2), 100-110.

Shofwan, I., Raharjo, J. T., Fakhruddin, Sutarto, J., \& Suminar, T. (2019). Non-Formal Learning Strategy Based On Tahfidz And Character In The Primary School. International Journal Of Scientific \& Technology Research, Vol.8(10).

Sihombing, U. (1999). Pendidikan Luar sekolah; Kini dan Masa Depan. Mahkota.

Smet, C. D., Valcke, M., Schellens, T., \& Wever, B. (2016). A Qualitative Study on Learning and Teaching With Learning Paths in a Learning Management System. Journal of Social Science Education, 15(no.1), 27-37.

Sudjana. (2004). Manajemen Program Pendidikan; untuk PNF dan Pengembangan Sumber Daya Manusia. Falah Production.

Sufyan, A., Nurhalim, K., \& Shofwan, I. (2019). Learning Management of Nonformal Education Units in Sanggar Kegiatan Belajar. Journal of Nonformal Education, 5(1), 57-66.
Terry, G. R. (2012). Giude to Management, edisi terjemah; Prinsip-Prinsip Manajemen oleh $J$. Smith. Bumi Aksara.

UNESCO. (2008). Community Learning Centres (CLC) Country Reports from Asia.

Widodo. (2015). Pengelolaan sanggar kegiatan belajar (SKB) pada era otonomi daerah. Jurnal Pendidikan Dan Pemberdayaan Masyarakat (JPPM), 2(1), 94-106.

Widodo. (2019). Models of Community Learning Centre (CLC) Management. 5th International Conference on Education and Technology (ICET), 121-126.

Yatimah, D. (2016). Dampak Implementasi Metode Pembelajaran Berbasis Masalah Pada Tutorial Program Paket B Binaan Pkbm Al Ishlah Jakarta Timur. Journal of Nonformal Education, 2(1), 3948.

Yoo, C. \&. (2012). Popular education for people's empowerment in the Community Learning Center (CLC) project in Bangladesh. Journal Korean Educational Development Institute (KEDI), 363-381.

Yukl, G. (2005). Leadership in Organization; (five editi). PT. Indeks.

Yusanto, I., \& Karebet, M. (2003). Manajemen Strategis: Perspektif Syariah. Khoirul Bayan. 